Protein malnutrition impairs the immune control of Trichinella spiralis infection

Cecilia C. Vila B.Sc, María P. Saracino Ph.D. ,

Guido H. Falduto Ph.D. , Marcela A. Calcagno B.Sc ,

Stella M. Venturiello Ph.D. , Anabel N. Pallaro Ph.D. ,

Pablo C. Baldi Ph.D.

PII:

DOI:

Reference:

To appear in:

Received date:

Revised date:

Accepted date:
S0899-9007(18)30895-5

https://doi.org/10.1016/j.nut.2018.10.024

NUT 10369

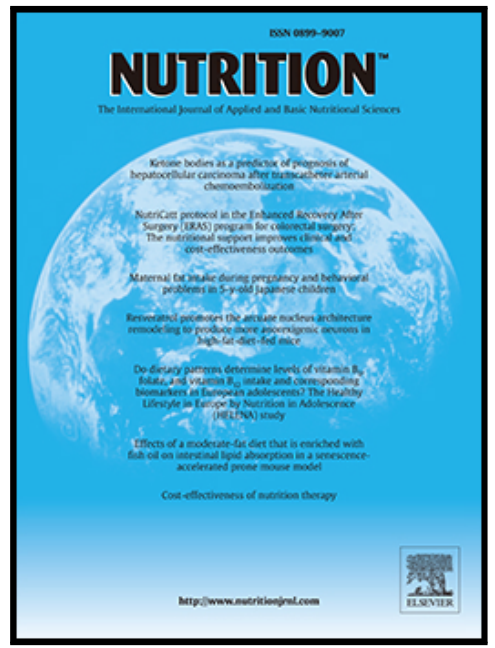

22 August 2018

21 September 2018

19 October 2018

Please cite this article as: Cecilia $C$ Marcela A. Calcagno B.Sc,

C. Vila B.Sc, María P. Saracino Ph.D., Guido H. Falduto Ph.D. , Stella M. Venturiello Ph.D. , Anabel N. Pallaro Ph.D. , Pablo C. Baldi Ph.D. , Protein malnutrition impairs the immune control of Trichinella spiralis infection, Nutrition (2018), doi: https://doi.org/10.1016/j.nut.2018.10.024

This is a PDF file of an unedited manuscript that has been accepted for publication. As a service to our customers we are providing this early version of the manuscript. The manuscript will undergo copyediting, typesetting, and review of the resulting proof before it is published in its final form. Please note that during the production process errors may be discovered which could affect the content, and all legal disclaimers that apply to the journal pertain. 


\section{Protein malnutrition impairs the immune control of Trichinella spiralis}

\section{infection}

Cecilia C. Vila B.Sc ${ }^{\text {a }}$, María P. Saracino Ph.D. ${ }^{\text {a }}$, Guido H. Falduto Ph.D. ${ }^{\text {a }}$, Marcela A.

Calcagno B.Sc ${ }^{\text {a }}$, Stella M. Venturiello Ph.D. ${ }^{\text {a }}$, Anabel N. Pallaro Ph.D. ${ }^{\text {b* }}$, Pablo C. Baldi Ph.D. ${ }^{\text {a\# }}$.

${ }^{a}$ Universidad de Buenos Aires, Facultad de Farmacia y Bioquímica, Departamento de Microbiología, Inmunología, Biotecnología y Genética, Cátedra de Inmunología, IDEHU-CONICET, Junín 956, 1113, Ciudad de Buenos Aires, Argentina.

${ }^{\mathrm{b}}$ Universidad de Buenos Aires, Facultad de Farmacia y Bioquímica, Departamento de Sanidad, Nutrición, Bromatología y Toxicología, Cátedra de Nutrición. Junín 956, 1113, Ciudad de Buenos Aires, Argentina.

*Corresponding author Tel.: +54 11 52874210. E-mail address: apallaro@ffyb.uba.ar (Anabel Pallaro).

\#Corresponding author Tel.: +54 11 52874417. E-mail address: pablobal@ffyb.uba.ar (Pablo Baldi). https://orcid.org/0000-0002-2500-6682.

Declarations of interest: None

\section{Protein malnutrition impairs the immune control of Trichinella spiralis}

\section{infection}

Highlights:

A protein deficient diet affected the immune response of rats to Trichinella spiralis The systemic eosinophilic response was more affected than the antibody response At the mucosal level both cellular and humoral responses were affected Parasite persistence in different tissues was longer in protein deficient rats Parasite fecundity index was higher in protein deficient rats 
Abstract

Objective We aimed to analyze the effect of a protein deficient diet on the mucosal and systemic immunity during Trichinella spiralis infection.

Methods Two groups of weaning Wistar rats received a protein deficient diet (PD, 6.5\% casein) and other two received a control diet (C, 20\% casein). After ten days, one group of each diet was infected $\left(\mathrm{PD}_{\mathrm{I}}\right.$ and $\left.\mathrm{C}_{\mathrm{I}}\right)$ with muscle larvae (ML, infecting stage). Food intake and body weight were assessed over time. Blood eosinophils counts, and antibodies in serum and tissue extracts were assessed at different days postinfection. Histological studies were done in lung and intestine; adult worm (AW) fecundity index and muscle parasite burden were determined.

Results 1) food and protein intake were lower in $\mathrm{PD}_{1}$ than in $\mathrm{C}_{\mathrm{I}}$; 2) body weight was lower in $\mathrm{PD}_{\mathrm{I}}$ than in non-infected PD; 3) eosinophils counts were lower in $\mathrm{PD}_{\mathrm{I}}$ than in $\mathrm{C}_{\mathrm{I}}$; 4) total and specific antibodies were lower in $\mathrm{PD}_{\mathrm{I}}$ than $\mathrm{C}_{\mathrm{I}}$; 5) $\mathrm{PD}_{\mathrm{I}}$ had reduced number of mast and goblet cells in lung and intestine compared to $C_{I}$; 6) persistence of $\mathrm{AW}$ at intestine and migrant larvae at lungs was longer in $\mathrm{PD}_{\mathrm{I}}$ than in $\mathrm{C}_{\mathrm{I}}$; 7) $\mathrm{AW}$ fecundity index was higher in $\mathrm{PD}_{\mathrm{I}}$ than in $\mathrm{C}_{\mathrm{I}}$; 8) $\mathrm{PD}_{\mathrm{I}}$ evidenced a higher muscular parasite burden than $\mathrm{C}_{\mathrm{I}}$.

Conclusions Protein deficiency affects the mucosal and systemic immune response to $T$. spiralis, delaying the expulsion and increasing the fecundity index of AW, and leading to a higher parasite burden in muscles.

Keywords. Protein deficiency; Trichinella spiralis infection; nutritional parameters; immunological parameters; parasitological parameters.

\section{Introduction}


It is known that the immune system is affected by malnutrition causing a higher susceptibility to infections [1]. Malnutrition and gastrointestinal nematode infections are chronic diseases that often co-exist in individuals from developing countries [2].

Trichinellosis is a foodborne parasitic disease acquired by the ingestion of either raw or undercooked meat infected with Trichinella spp. muscle larvae (ML). In the stomach, ML are released and penetrate the epithelial layer of the gut, where they molt into adult worms (AW). After mating, female AW release migrant or newborn larvae (NBL) on days 5-6 post-infection (p.i.), which go through the bloodstream and lymphatic system passing through different organs, including the lungs, during their migration to the skeletal muscle [3]. Each larva enters a muscle cell where they develop into ML [4].

The effector immunological response against $T$. spiralis is focused on two parasitic stages: at the gut level, AW are expelled by the combined action of cellular (mast and goblet cells) and humoral responses [5-7]; at the systemic level, NBL are killed by antibody dependent cellular cytotoxicity (ADCC) [8-10]. Recent results from our laboratory have demonstrated an allergic-like inflammatory response in the lung parenchyma with bronchus-associated lymphoid tissue (BALT) hyperplasia before and during NBL passage through this organ [11-12]. In particular, there is an increase of mast cells, eosinophils and goblet cells. Moreover, retention and destruction of NBL by ADCC were shown to take place in the lungs of infected rats [13]. The responses described above are globally described as type 2 immune responses and include both innate and adaptive components. Among the latter, the induction of a T helper 2 (Th2) phenotype with production of IL-4, IL-5 and IL-13 cytokines is of utmost importance for inducing and sustaining Type 2 responses. Whereas helminth infections induce a 
Th2 immune response, protein deficiency promotes higher levels of Th1 cytokines and diminishes Th2 effector cells [14].

Whereas several studies have explored the impact of protein deficiency on the outcome of helminth infections, to our best knowledge only two previous studies evaluated these issues in T. spiralis infections [15-16]. Although both studies revealed a link between protein deficiency and delayed worm expulsion or increased numbers of muscle larvae, the immunological determinants of this impaired infection control were not assessed. In the present study we evaluated the parasitological, histological and immunological consequences of protein deficiency in the context of a $T$. spiralis infection in weaning rats. This study is the first one to assess the impact of protein deficiency not only on the intestinal specific immune response, but also on the pulmonary immune response, which was recently shown to be involved in the control of T. spiralis infection.

\section{Materials and methods}

\section{Animals and infection}

Weaning femalé Wistar rats (21-23 days old) weighing an average of $42.21 \pm$ $1.92 \mathrm{~g}$ (initial $\mathrm{BW}\left[\mathrm{BW}_{\mathrm{i}}\right]$ ) were housed individually in screen-bottomed cages and exposed to a 12-h light-dark cycle. Room temperature was kept at $21.0 \pm 1.0{ }^{\circ} \mathrm{C}$, and animals were provided with water and food ad libitum. They were divided into four groups of five animals each: two groups received a protein deficient diet (PD) and the others received a control diet for growing rats $(\mathrm{C})$.

After ten days, one group of each diet was orally infected, through a feeding probe, with $900 \mathrm{ML}$ of $T$. spirallis per rat $\left(\mathrm{PD}_{\mathrm{I}}, \mathrm{C}_{\mathrm{I}}\right)$ suspended in saline solution. $\mathrm{ML}$ 
were obtained from muscle tissue of infected Swiss mice by the artificial digestion method [17]. The other groups were used as non-infected controls $\left(\mathrm{PD}_{\mathrm{NI}}, \mathrm{C}_{\mathrm{NI}}\right)$.

All experimental protocols were approved by the Institutional Committee of Care and Use of Laboratory Animals (CICUAL-FFyB, Res $N^{\circ} 2470 / 17$ ).

\section{Experimental diets}

$\mathrm{PD}$ and $\mathrm{C}$ groups received experimental isocaloric diets that provided $6.5 \%$ or $20 \%$ protein, respectively, and all the essential nutrients as recommended by the American Institute of Nutrition [18]. Casein (Friesl and Campina, 89.2\%) was incorporated, as the only source of protein, to provide the required protein concentration. Choline, soy oil, and a vitamin and mineral mix were added, and the mixture was then filled up to $1000 \mathrm{~g}$ by adding dextrin, as previously reported [19].

\section{Nutritional parameters}

BW (g) and food intake (g/day) were recorded from the first day of diet administration. At the end of the experimental period, the diets were withheld for $4 \mathrm{~h}$, the final $\mathrm{BW}\left(\mathrm{BW}_{\mathrm{f}}\right)$ was determined, and the ponderal growth rate (PGR, expressed as $\mathrm{g}$ per $100 \mathrm{~g}$ of rat per day) was calculated as follows:

$\mathrm{PGR}=\left[\left(\mathrm{BW}_{\mathrm{f}}-\mathrm{BW} \mathrm{i}\right) / \mathrm{n}\right.$ days $] /\left[\left(\mathrm{BW}_{\mathrm{i}}+\mathrm{BW}_{\mathrm{f}}\right) / 2\right] \times 100(1)$

Daily protein and energy intake were measured and expressed as $\mathrm{mg} / \mathrm{BW}^{0.75} / \mathrm{day}$ and $\mathrm{kcal} / \mathrm{BW}^{0.75} / \mathrm{day}$, respectively, where $\mathrm{BW}^{0.75}$ is the metabolic mass.

\section{Blood samples}

Blood samples were obtained from all groups at different post-infection (p.i.) times by tail vein puncture, using heparin as anticoagulant when necessary (eosinophil 
counts). At day 33 p.i., blood was obtained by cardiac puncture. Serum samples were aliquoted and kept at $-70{ }^{\circ} \mathrm{C}$ until use.

\section{Blood eosinophils counts}

Blood eosinophils were determined by counting cells in a Fusch-Rosenthal hemocytometer after staining whole blood with Discombe's solution [20].

Detection of total serum immunoglobulins (IgGAM) and IgE against muscle larvae excretory-secretory products (ML-ESP) by ELISA

Serum IgG, IgA and IgM (IgGAM) and serum IgE specific for Trichinella were detected by indirect ELISA as described previously [12]. Plates coated with ML-ESP were incubated with serum samples and, after washing, were incubated with either a biotinylated anti-rat IgGAM serum (Véctor Laboratories, Burlingame, CA, USA), followed by a complex of avidin and biotinylated peroxidase (Vector), or a goat anti-rat $\varepsilon$ chain serum (Bethyl Laboratories, TX, USA), followed by a horseradish peroxidaseconjugated rabbit anti-goat serum (Bethyl). Colour reaction was developed with ophenylenediamine $/ \mathrm{H}_{2} \mathrm{O}_{2}$ for $\operatorname{IgGAM}$, or with tetramethylbenzidine for IgE. Reaction was stopped by adding $4 \mathrm{~N} \mathrm{H}_{2} \mathrm{SO}_{4}$, and the optical density (OD) was read in an ELISA reader at $490 \mathrm{~nm}$ for IgGAM and $450 \mathrm{~nm}$ for IgE.

\section{Histological studies in lung and intestine}

Rats were euthanized by cardiac puncture under anesthesia in order to obtain lungs and intestine. Tissues were perfused by injecting PBS with heparin (10 IU/mL) into the right cardiac ventricle. The organs were removed and tissue sections were obtained using the Sainte-Marie technique [21]. Tissue sections were stained with 
Giemsa (general aspects of the tissues), Alcian Blue Safranin (mast cells) and Haematoxilin-PAS (goblet cells).

Goblet cells were counted in 15 villous crypt units (VCU) in the intestine epithelium. In the lungs, goblet cells were counted in the epithelium located close to the BALT. Mast cells were counted in $15 \mathrm{VCU}$ in the gut lamina propria. In the lung parenchyma mast cells were counted in 100 randomly selected fields for each sample, employing a grid with a known area $\left(62,500 \mu \mathrm{m}^{2}\right)$. All counts were made at $400 \times$ magnification by two independent observers.

\section{Tissue extracts preparation}

Lung and intestine tissue extracts (LTE and ITE, respectively) were obtained using the PERFEXT method [22] with slight modifications. Briefly, the rats were euthanized and infused with PBS plus heparin $(5000 \mathrm{UI} / \mathrm{ml})$ into the heart. The perfused organs were cut into small pieces, placed in an extraction solution containing CHAPS $90 \mathrm{mM}$ in PBS and protease inhibitors, and frozen at $-70{ }^{\circ} \mathrm{C}$. After thawing, the extraction was performed overnight at $4{ }^{\circ} \mathrm{C}$ using a homogenizer. After centrifugation, the supernatants were collected, filtered through a $0.22 \mu \mathrm{m}$ filter, aliquoted and kept frozen at $-70^{\circ} \mathrm{C}$ until use.

Detection of total and specific antibodies in LTE and ITE

Total $\operatorname{Ig} \mathrm{A}, \operatorname{IgE}, \operatorname{IgG} 1$ and $\operatorname{IgG} 2 \mathrm{a}$ were determined by a capture ELISA commercial kit (Bethyl Laboratories).

Levels of anti-ML-ESP and anti-AW-ESP IgA, IgE, IgG1 and IgG2a were determined by indirect ELISA as described previously [12, 23]. 
Fecundity index of female $A W$

To estimate the fecundity index of female AW, the method described by Marti and Murrell (1986) was employed [24], with slight modifications. After recovery of AW from intestine by Baermann separation, females were identified and counted. Worms were incubated at $37^{\circ} \mathrm{C}$ in $5 \% \mathrm{CO}_{2}$ in RPMI supplemented with antibiotics and $5 \%$ fetal calf serum. After $3 \mathrm{~h}$, the number of NBL shed by female worms was counted and the fecundity index was calculated as the number of NBL/female AW.

\section{Determination of parasite burden}

ML recovered from the carcasses of infected rats by the artificial digestion method [17] at day 33 p.i. were washed, suitably diluted in saline and mixed 1:1 with agar $1.5 \%$. Mixtures were placed in grooved Petri dishes and allowed to solidify. ML were counted by two independent observers using an optical microscope.

\section{Statistical analysis}

Parasite burden was analysed using the unpaired $t$ test. PGR, food, energy and protein intake were analysed using the one-way ANOVA test, employing Tukey's multiple comparisons test for post-hoc analysis. BW, cell counts, total and specific isotypes and fecundity index were analysed using the two-way ANOVA test, employing Tukey's and/or Sidak's multiple comparisons test for post hoc analysis. Data were analyzed using the GraphPad Prism 6 software and a $P<0.05$ was considered significant.

\section{Results}


BW was significantly lower in $\mathrm{PD}_{\mathrm{I}}$ than in $\mathrm{C}_{\mathrm{I}}$ animals before the infection (48.02 \pm 2.32 vs. $76.68 \pm 2.04 \mathrm{~g}$ at day 9 of the diet, $P<0.01$, Fig. 1, Table 1). This pattern was observed during all the experiment, with the highest difference at the end of the experimental period (day 43 of the diet: $55.67 \pm 1.87$ vs. $174.80 \pm 4.47 \mathrm{~g}, P<0.0001$, Fig. 1). In addition, a significant difference was observed between $\mathrm{PD}_{\mathrm{I}}$ and $\mathrm{PD}_{\mathrm{NI}}$ rats at the end of the study $(55.67 \pm 1.87$ vs. $73.64 \pm 2.62 \mathrm{~g}, P<0.05$, Fig. 1$)$.

PGR was significantly lower in $\mathrm{PD}_{\mathrm{I}}$ than in $\mathrm{C}_{\mathrm{I}}$ rats $(1.53 \pm 0.73$ vs. $6.69 \pm 0.57$ $\mathrm{g} / 100 \mathrm{~g}$ of rat per day, $P<0.0001$, Table 1$)$ during the feeding period before infection. In addition, the same pattern was observed during the total period $(0.63 \pm 0.35$ vs. $2.87 \pm$ $0.40 \mathrm{~g} / 100 \mathrm{~g}$ of rat per day, $P<0.05)$.

During the infection, $\mathrm{PD}_{\mathrm{I}}$ rats showed a lower $\mathrm{PGR}$ compared to $\mathrm{PD}_{\mathrm{NI}}$ rats $(0.30$ \pm 0.46 vs. $1.22 \pm 0.48 \mathrm{~g} / 100 \mathrm{~g}$ of rat per day, $P<0.01$, Table 1$)$. However, no significant differences in PGR were observed between $\mathrm{C}$ groups throughout the period.

Food intake during the whole study was significantly lower in $\mathrm{PD}_{\mathrm{I}}$ than in $\mathrm{C}_{\mathrm{I}}$ rats $(8.83 \pm 1.68$ vs. $14.25 \pm 1.94$ g/day, $P<0.05$, Table 1$)$. Regardless of the infection status, $\mathrm{PD}$ groups had lower protein intake than $\mathrm{C}$ groups $\left(\mathrm{PD}_{\mathrm{I}}: 31.26 \pm 3.28\right.$ vs. $\mathrm{C}_{\mathrm{I}}$ : $84.46 \pm 4.30 \mathrm{mg} / \mathrm{BW}^{0.75} / \mathrm{day}, P<0.005$, Table 1$)$. Finally, there were no differences in the energy intake among groups.

\section{Blood eosinophils counts}

Compared to their non-infected counterparts, eosinophils counts started to increase at day 5 p.i. in $\mathrm{PD}_{\mathrm{I}}$ animals $\left(91.67 \pm 2.08\right.$ vs. $24.71 \pm 3.41$ cells $/ \mathrm{mm}^{3}, P=$ 0.0001, Fig. 2), whereas this occurred at day 3 p.i. in $C_{I}$ animals (83.33 \pm 5.51 vs. 20.51 \pm 2.17 cells $\left./ \mathrm{mm}^{3}, P=0.0003\right)$. 
On day 11 p.i. both infected groups reached the maximum number of eosinophils, without significant differences between them. However, counts were significantly lower in $\mathrm{PD}_{\mathrm{I}}$ than in $\mathrm{C}_{\mathrm{I}}$ animals on days $3,5,15$ and 20 p.i. The largest difference was found on day 5 p.i. $\left(91.67 \pm 2.08\right.$ vs $162.50 \pm 16.54$ cells $/ \mathrm{mm}^{3}, P<$ 0.0001). At the end of the experiment, eosinophils counts in $\mathrm{PD}_{\mathrm{I}}$ returned to baseline levels earlier than those in $\mathrm{C}_{\mathrm{I}}$.

Determination of IgGAM and IgE against ML-ESP in sera

OD values of specific IgGAM and IgE were similar and followed the same kinetics in $\mathrm{PD}_{\mathrm{I}}$ and $\mathrm{C}_{\mathrm{I}}$ animals. For both groups values were positive (above cut-off) from day 11 p.i., reaching the maximum value at day 33 p.i. (Fig. 3).

Histological analysis of intestine and lungs

Gut villi of $\mathrm{PD}$ rats $\left(\mathrm{PD}_{\mathrm{I}}, \mathrm{PD}_{\mathrm{NI}}\right)$ showed a decrease in size (Fig. 4, $\mathrm{C}$ and $\left.\mathrm{G}\right)$, and during the infection period $\mathrm{PD}_{\mathrm{I}}$ and $\mathrm{C}_{\mathrm{I}}$ groups showed an inflammatory process at the intestine (Fig. 4, E and G) and at the BALT (Fig. 4, F and H).

Intestinal and pulmonary numbers of goblet cells increased later in $\mathrm{PD}_{\mathrm{I}}$ than in $\mathrm{C}_{\mathrm{I}}$. As compared to NI controls, intestinal goblet cells increased from day 6 p.i. in $\mathrm{C}_{\mathrm{I}}$ $(21.81 \pm 1.70$ vs. $11.20 \pm 0.92$ cells/VCU, $P<0.005$, Fig. $5 \mathrm{~A})$, and from day 9 p.i. in $\mathrm{PD}_{\mathrm{I}}(18.80 \pm 1.53$ vs. $9.77 \pm 1.26$ cells/VCU, $P<0.01)$. As compared to NI controls, goblet cells in the lung parenchyma increased from day 3 p.i. in $C_{I}(7.68 \pm 0.76 v s .1 .00$ \pm 1.00 cells/100 lung cells, $P<0.005$, Fig. 5B), and from day 9 p.i. in $\mathrm{PD}_{\mathrm{I}}(9.00 \pm 1.00$ vs. $0.33 \pm 0.76$ cells/100 lung cells, $P<0.001)$.

Mast cells in lung and intestine also increased with a delay in $\mathrm{PD}_{\mathrm{I}}$ as compared to $\mathrm{C}_{\mathrm{I}}$. Intestinal mast cells increased from day 6 p.i. in $\mathrm{C}_{\mathrm{I}}(35.63 \pm 2.84$ vs. $5.6 \pm 1.46$ 
cells/VCU, $P<0.001$, Fig. 5C), and from day 9 p.i. in $\mathrm{PD}_{\mathrm{I}}(26.47 \pm 2.73 v s .4 .07 \pm 0.90$ cells/VCU, $P<0.01)$. In the lungs, mast cells increased from day 3 p.i. in $\mathrm{C}_{\mathrm{I}}(12.25 \pm$ 1.28 vs. $5.41 \pm 1.16$ cells $/ \mathrm{mm}^{2}, P<0.01$ Fig. $\left.5 \mathrm{D}\right)$, and from day 9 p.i. in $\mathrm{PD}_{\mathrm{I}}(11.19 \pm$ 1.41 vs. $4.08 \pm 1.31$ cells $\left./ \mathrm{mm}^{2}, P<0.01\right)$.

Although AW are usually expelled from the gut at day 13-15 p.i. in the rat model, they were found in the intestine of $\mathrm{PD}_{\mathrm{I}}$ rats as long as day 33 p.i. (Fig. 4, G and I). Also, at day 33 p.i. NBL were found in lungs of $\mathrm{PD}_{\mathrm{I}}$ rats (Fig. $4 \mathrm{~J}$ ) but not in $\mathrm{C}_{\mathrm{I}}$ controls.

Detection of total and specific isotypes in ITE and LTE

In ITE, total IgE levels were lower in $\mathrm{PD}_{\mathrm{I}}$ than in $\mathrm{C}_{\mathrm{I}}$ (day 9 p.i. $31.22 \pm 5.08$ vs. $183.05 \pm 11.19 \mathrm{ng} / \mathrm{ml}, P<0.01$ ) (Fig. 6). Total IgA decreased in $\mathrm{C}_{\mathrm{I}}$ since day 3 p.i., but maintained its level in $\mathrm{PD}_{\mathrm{I}}$ during the whole follow-up. Total IgG1 increased over time in both $\mathrm{C}_{\mathrm{I}}$ and $\mathrm{PD}_{\mathrm{I}}$. Regarding anti ML-ESP antibodies, IgE, IgG1 and IgG2a were increased in $\mathrm{C}_{\mathrm{I}}$ group since day 9 p.i., whereas the $\mathrm{PD}_{\mathrm{I}}$ group showed a non-significant increase. In the case of specific antibodies against AW-ESP, all isotypes were present in the $\mathrm{C}_{\mathrm{I}}$ group, whereas in $\mathrm{PD}_{\mathrm{y}}$ only $\operatorname{IgG} 2 \mathrm{a}$ had a significant increase.

In LTE(Fig. 7) all isotypes of total antibodies were reduced in $\mathrm{PD}_{\mathrm{I}}$ compared to $\mathrm{C}_{\mathrm{I}}$ (IgE: day 9 p.i. $76.58 \pm 6.07$ vs. $217.83 \pm 12.55 \mathrm{ng} / \mathrm{ml}, P<0.05$; $\operatorname{IgA}$ : day 9 p.i. $384.02 \pm 9.55$ vs. $909.14 \pm 17.99 \mu \mathrm{g} / \mathrm{ml}, P<0.05 ; \mathrm{IgG} 1$ : day 13 p.i. $3226.45 \pm 30.95$ vs. $5679.25 \pm 61.55 \mathrm{ng} / \mathrm{ml}$; IgG2a: day 3p.i. $766.05 \pm 15.83$ vs. $2271.60 \pm 24.52, \mathrm{ng} / \mathrm{ml}$ $P<0.01)$. Specific IgA and IgG1 were present in both groups since day 13 p.i.

Fecundity index of female $A W$ 
In all the p.i. days studied, the parasite fecundity index was higher in $\mathrm{PD}_{\mathrm{I}}$ than in $\mathrm{C}_{\mathrm{I}}$ (Fig. 8), but this difference began to be significant at day 9 p.i. $(30.58 \pm 3.39 v \mathrm{v}$. $14.32 \pm 2.95, \mathrm{NBL} /$ female AW $P<0.05)$. At day 20 p.i., a time point at which normally AW have been completely expelled in well-nourished rats, not only were AW still present in the $\mathrm{PD}_{\mathrm{I}}$ group but they were still releasing NBL $(14.05 \pm 2.30$ vs. $0 \pm 0$, NBL/female AW $P<0.05)$.

\section{Parasite burden}

At 33 days p.i. the parasite burden in muscle was 10 times higher in $\mathrm{PD}_{\mathrm{I}}$ than in $\mathrm{C}_{\mathrm{I}}$ animals $(10,069.99 \pm 3,077.16$ vs. $1048.53 \pm 206.85 \mathrm{ML} / \mathrm{g}, P<0.01$, Fig. 9). Physical deterioration was observed in $\mathrm{PD}_{\mathrm{I}}$ rats, the only group that recorded 2 deaths (on days 25 and 32 p.i.). In the case of $\mathrm{C}_{\mathrm{I}}$, no physical deterioration was observed.

\section{Discussion}

Although previous studies analyzed the consequences of PD on the course of $T$. spiralis infection (in terms of worm expulsion or larval load in muscles) [15-16], the effects of PD on cellular and humoral immune factors involved in the control of such infection have not been assessed. In this study we analyzed the parasitological, histological and immunological consequences of PD, at both the gut and the lung level, in $T$. spiralis-infected rats.

The administration of the PD diet provoked a severe delay in the growth of the animals, which was observed from the first days of treatment before the infection. However, the lower $\mathrm{BW}$ and $\mathrm{PGR}$ of $\mathrm{PD}_{\mathrm{I}}$ compared to $\mathrm{PD}_{\mathrm{NI}}$ group at the end of the study confirmed the negative effect of the combination of malnutrition and infection. As in our previous studies, no deaths were recorded among uninfected rats fed the protein 
deficient diet [19]; however, the addition of Trichinella spiralis infection ( $\mathrm{PD}_{\mathrm{I}}$ group) provoked a higher morbidity and led to death in two cases. No deaths were reported by Gbarkima [16] in protein deficient mice infected with T. spiralis, but the low protein diet was begun later than in the present study (two weeks after weaning).

Previous studies showed that a low protein concentration and a low quality of dietary protein impair mucosal immunity [25]. In the present study, the $\mathrm{PD}_{\text {I }}$ group not only showed a decrease in gut villi size and a lower number of mast and goblet cells during the first month p.i., but also AW were found at day 33 p.i., when in the rat model they are normally expelled on days 13-14 p.i. [26], indicating that the parasite rejection is delayed in these animals. Our results are in line with previous studies on $T$. spiralis and other helminth infections in adult mice with protein malnutrition [16, 27-29]. Regarding the humoral response in the gut mucosa, the $\mathrm{PD}_{\mathrm{I}}$ group showed lower levels of total and specific antibodies probably due to a decreased protein synthesis as a consequence of the lower protein intake. This phenomenon has been also observed in malnourished mice with schistosomiasis [30]. Altogether, these results indicate a diminished mucosal immune response in $\mathrm{PD}_{\mathrm{I}}$ animals, at both cellular and humoral levels, which would facilitate the persistence of the AW in the gut.

Specifie $\operatorname{IgE}$ and $\operatorname{Ig} \mathrm{A}$ present in the intestinal mucosa are known to reduce the fecundity of the AW, thus limiting the production of NBL and the subsequent invasion of the skeletal muscle [31]. In this work, levels of specific $\operatorname{Ig} \mathrm{A}$ and $\operatorname{IgE}$ were lower in the $\mathrm{PD}_{Y}$ group, which could reduce the detrimental effect of these antibodies on AW fecundity, thus allowing a higher number of NBL to birth and reach the systemic circulation. The higher fecundity index in the $\mathrm{PD}_{\mathrm{I}}$ group is in line with the results of specific antibodies. In addition, in the $\mathrm{PD}_{\mathrm{I}}$ group NBL production was prolonged until at least day 20 p.i., whereas this phenomenon normally finishes on day 13-14 p.i. in well- 
nourished animals [26]. To our best knowledge this is the first study evaluating the fecundity index of $T$. spiralis in PD animals.

NBL migrates through the lymph and blood system of the host, being the second target of the immune response. In the murine model, there is a systemic response characterized by eosinophilia and an increase of specific Igs levels [32]. In this work, $\mathrm{PD}_{\mathrm{I}}$ animals had decreased eosinophils counts, but serum levels of anti ML-ESP IgGAM and IgE were not affected. These results suggest that at a systemic level, the cellular immune response may be more affected than the humoral response. In contrast to what we found here, Boulay et al. (1998) [33] reported that during Heligmosomoides polygyrus infection blood eosinophilia as well as serum levels of Igs were decreased in PD animals.

We have previously shown that during NBL migration there is an allergic-like inflammatory response in the lung parenchyma that includes mucosal mastocytosis and goblet cells hyperplasia [12-13]. This pulmonary response generates a suitable scenario for the attack of NBL by immunological effectors. The present study is the first to assess the effect of PD on parasitological, histological and immunological parameters in the lungs of $T$. spiralis-infected animals. The $\mathrm{PD}_{\mathrm{I}}$ group had reduced mast and goblet cells counts in lungs, suggesting that the pulmonary mucosal cellular response is affected by protein deficiency. However, the local humoral response did not seem to be affected as levels of specific antibodies in lung extracts did not differ between $\mathrm{C}_{\mathrm{I}}$ and PD groups. Nevertheless, NBL were observed as long as 33 days p.i. in the lungs of the $\mathrm{PD}_{\mathrm{I}}$ group, being the first time that this long persistence is reported. This suggests that the lung cellular immune response has a key role in the control of NBL migration.

Overall, these results suggest that the higher parasite burden found in the $\mathrm{PD}_{\mathrm{I}}$ group may be associated with the longer persistence of AW in the intestine and the 
higher fecundity index of female AW, which are consequences of the lower humoral and cellular immune response. The reduced number of blood eosinophils in the $\mathrm{PD}_{\mathrm{I}}$ group may also compromise the systemic immunological effector mechanisms against NBL, contributing to the higher parasite burden in muscles. Further studies will be required to determine whether the $\mathrm{ADCC}$ mechanism against NBL is affected by protein deficiency.

In summary, protein deficiency diminishes the intestinal, pulmonary and systemic immune response to $T$. spiralis, delaying the expulsion and increasing the fecundity index of AW. These alterations are associated with a higher parasite burden in muscles.

\section{Acknowledgments}

The authors acknowledge the skillful assistance of Ms. Cecilia Mambrín in the care, breeding, and diet preparation of the animals.

This work was supported by grants from the National Council of Scientific and Technical Research (CONICET, PIP 0973) and the Universidad de Buenos Aires (UBACyT 20020130100652BA).

\section{References}

1. Chandra RK (1983) Nutrition, immunity and infection: present knowledge and future directions. Lancet 1:688-691. doi: 10.1016/S0140-6736(83)91980-3.

2. Koski KG and Scott ME (2001) Gastrointestinal Nematodes, Nutrition and Immunity: Breaking the Negative Spiral. Annu Rev Nutr 21:297-321. doi: 10.1146/annurev.nutr.21.1.297.

3. Despommier DD, Gwadz RW, Hotez PJ, Knirsch CA (2005) The nematodes. In: Despommier, DD, Gwadz, RW, Hotez, PJ, Knirsch, CA (Eds.), Parasitic Diseases. 
Apple Trees Productions, L.L.C., New York, pp. 105-174. ISBN: 978-0-9978400$1-8$.

4. Wu Z, Sofronic-Milosavljevic L, Nagano I, Takahashi Y (2008) Trichinella spiralis: nurse cell formation with emphasis on analogy to muscle cell repair. Parasites \& Vectors 1:27. doi:10.1186/1756-3305-1-27.

5. Negrao-Correa D, Adams LS, Bell RG (1999) Variability of the intestinal immunoglobulin E response of rats to infection with Trichinella spiralis, Heligmosomoides polygyrus or Nippostrongylus brasiliensis. Parasite Immunol 21:287-297. doi:10.1046/j.1365-3024.1999.00219.x.

6. Ahmad A, Wang CH, Bell RG (1991) A role for IgE in intestinal immunity. Expression of rapid expulsion of Trichinella spiralis in rats transfused with IgE and thoracic duct lymphocytes. J Immunol 146:3563-3570. Online ISSN 1550-6606.

7. Suzuki T, Sasaki T, Takagi H, Sato K, Ueda K (2008) The effectors responsible for gastrointestinal nematode parasites, Trichinella spiralis, expulsion in rats. Parasitol Res 103:1289-1295. doi: 10.1007/s00436-008-1130-1.

8. Gansmuller A, Anteunis A, Venturiello SM, Bruschi F, Binaghi RA (1987) Antibodydependent in vitro cytotoxicity of newborn Trichinella spiralis larvae: nature of the cells involved. Parasite Immunol 9:281-292. doi:10.1111/j.13653024.1987.tb00508.x.

9. Wang CH, Bell RG (1988) Antibody-mediated in vivo cytotoxicity to Trichinella spiralis newborn larvae in immune rats. Parasite Immunol 10:293-308. doi:10.1111/j.1365-3024.1988.tb00222.x.

10. Venturiello SM, Giambartolomei GH, Costantino SN (1993) Immune killing of newborn Trichinella spiralis larvae by human leukocytes. Parasite Immunol 15:559-564. doi: 10.1111/pim.1993.15.10.559 
11. Venturiello SM, , Verzoletti ML, Costantino SN, Forastiero MA, Roux ME (2007) Early pulmonary response in rats infected with Trichinella spiralis. Parasitology 134:281-288. doi: 10.1017/S0031182006001454.

12. Gentilini MV, Nuñez GG, Roux ME, Venturiello SM (2011) Trichinella spiralis infection rapidly induces lung inflammatory response. The lung as the site of helminthocytotoxic activity. Immunobiol 216:1154-1163. doi: 10.1016/j.imbio.2011.02.002.

13. Falduto GH, Vila CC, Saracino MP, Calcagno MA, Venturiello SM (2015) Trichinella spiralis: killing of newborn larvae by lung cells. Parasitol Res 114:679685. doi: 10.1007/s00436-014-4233-x.

14. Ing R, Su Z, Scott ME, Koski KG (2000) Suppressed T helper 2 immunity and prolonged survival of a nematode parasite in protein-malnourished mice. Proc Natl Acad Sci USA 13:7078-7083. doi: 10.1073/pnas.97.13.7078.

15. Saowakontha S (1975) The relationship between protein-calorie malnutrition and trichinosis. II. Immunological response in rats fed low and high protein diets. Southeast Asian J Trop Med Public Health 6(1):79-81.

16. Gbakima AA (1993) The effect of dietary protein on Trichinella spiralis infection and inflammatory reactions in the tongue in CD1 mice. Nutr Res 13:787-800. doi: 10.1016/S0271-5317(05)80803-6.

17. Nöckler K, Kapel CMO (2007) Detection and surveillance for Trichinella: meat inspection and hygiene, and legislation. In: Dupouy-Camet J, Murrell KD (eds) FAO/WHO/OIE Guidelines for the surveillance, management, prevention and control of trichinellosis. pp 69-98. ISBN: 978-92-9044-704-7.

18. American Institute of Nutrition (1993) AIN-93 purified diets for laboratory rodents. Final report of American Institute of Nutrition ad hoc writing committee on the 
reformulation on the AIN-76A rodent diet. J Nutr 123:1939-1951. doi: 10.1093/jn/123.11.1939.

19. Pallaro A, Roux ME, Slobodianik NH (2001) Nutrition disorders and immunologic parameters: study of the thymus in growing rats. Nutrition 17:724-728. doi: 10.1016/S0899-9007(01)00614-1.

20. Discombe G (1964) Criteria of eosinophilia. Lancet 1:195-197. doi: 10.1016/S0140-6736(46)91306-2.

21. Sainte-Marie G (1961) A paraffin embedding technique for studies employing immunofluorescence. J Histochem Cytochem 10:250-256. doi: 10.1177/10.3.250.

22. Villavedra M, Carol H, Hjulström M, Holmgren J, Czerkinsky C (1997) "PERFEXT": a direct method for quantitative assessment of cytokine production in vivo at the local level. Res Immunol 148:257-266. doi: 10.1016/S09232494(97)80867-X.

23. Nuñez GG, Costantino SN, Venturiello SM (2003) Immunoparasitological parameters of the intestinal phase of trichinellosis in rats. Parasitology 126:321325. doi: 10.1016/j.trstmh.2008.03.009.

24. Marti HP, Murrell KD (1986) Trichinella spiralis: antifecundity and antinewborn larvae immunity in swine. Exp Parasitol 62:370-375. doi: 10.1016/00144894(86)90044-5.

25. Vidueiros SM, Fernandez I, Slobodianik N, Roux ME, Pallaro A (2008) Nutrition disorder and immunologic parameters: study of the intestinal villi in growing rats. Nutrition 24:575-581. doi: 10.1016/j.nut.2008.01.055.

26. Stewart GL, Na H, Smart L, Seelig LL (1999) The temporal relationship among antiparasite immune elements expressed during the early phase of infection of the rat with Trichinella spiralis. Parasitol Res 85:672-677. doi: 10.1007/s004360050613. 
27. Bolin TD, Davis AE, Cummins AG, Duncombe VM, Kelly JD (1977) Effect of iron and protein deficiency on the expulsion of Nippostrongylus brasiliensis from the small intestine of the rat. Gut Mar 18(3):182-186. doi: dx.doi.org/10.1136/gut.18.3.182.

28. Duncombe VM, Bolin TD, Davis A, Kelly JD (1979) The effect of iron and protein deficiency on the development of acquired resistance to reinfection with Nippostrongylus brasiliensis in rats. Am J Clin Nutr 32(3):553-558. doi: 10.1093/ajcn/32.3.553.

29. Michael E, Bundy DA (1991) The effect of the protein content of CBA/Ca mouse diet on the population dynamics of Trichuris muris (Nematoda) in primary infection. Parasitology 103 Pt 3:403-411. doi: 10.1017/S0031182000059928.

30. Coutinho EM (2004) Malnutrition and hepatic fibrosis in murine schistosomiasis. Mem Inst Oswaldo Cruz 99(5 Suppl 1):85-92. doi: S0074-02762004000900015.

31. DeVos T, Danell G, Dick TA (1992) Trichinella spiralis: Dose dependence and kinetics of the mucosal immune response in mice. Exp Parasitol 75:99-111. doi: $10.1016 / 0014-4894(92) 90125-\mathrm{T}$.

32. Del Prete G, Chiumiento L, Amedei A, Piazza M, D'Elios MM, Codolo G, de Bernard M, Masetti M, Bruschi F (2008) Immunosuppression of Th2 responses in Trichinella spiralis infection by Helicobacter pylori neutrophil-activating protein. J Allergy Clin Immunol 122(5):908-913.e5. doi: 10.1016/j.jaci.2008.08.016.

33. Boulay M, Scott ME, Conly SL, Stevenson MM, Koski KG (1998) Dietary protein and zinc restrictions independently modify a Heligmosomoides polygyrus (Nematoda) infection in mice. Parasitology 116:449-462 doi: 10.1017/S0031182098002431. 


\section{Figure legends}

Fig. 1
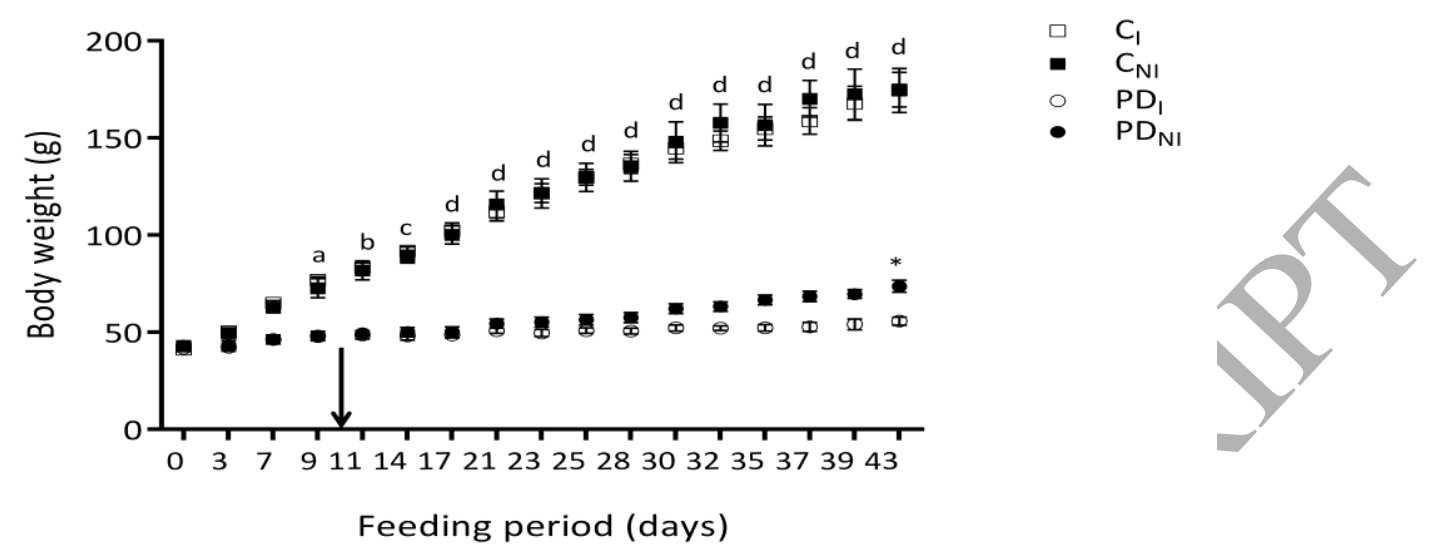

Fig. 1. BW during feeding period. BW were registered during all the experiment and results are expressed as the mean of the BW/rat $(\mathrm{g}) \pm$ S.E.M. Animals groups $(\mathrm{n}=$ 5/group) $\mathrm{C}$ and $\mathrm{PD}$ were infected with $T$. spiralis $\left(\mathrm{C}_{\mathrm{I}}\right.$ and $\left.\mathrm{PD}_{\mathrm{I}}\right)$ or non-infected $\left(\mathrm{C}_{\mathrm{NI}}\right.$ and $\left.\mathrm{PD}_{\mathrm{NI}}\right)$. The arrow indicates the beginning of the infection. Data were analyzed by twoway ANOVA test $(\alpha=0.05)$ followed by Tukey's multiple comparisons test. The asterisk indicates significant differences between $\mathrm{PD}_{\mathrm{I}}$ and $\mathrm{PD}_{\mathrm{NI}}(* P<0.05)$, and letters indicate significant differences between $\mathrm{C}$ and $\mathrm{PD}$ groups (a, $P<0.05 ; \mathrm{b}, P<0.01 ; \mathrm{c}, P$ $<0.005 ; \mathrm{d}, P<0.0001)$. 
Fig. 2

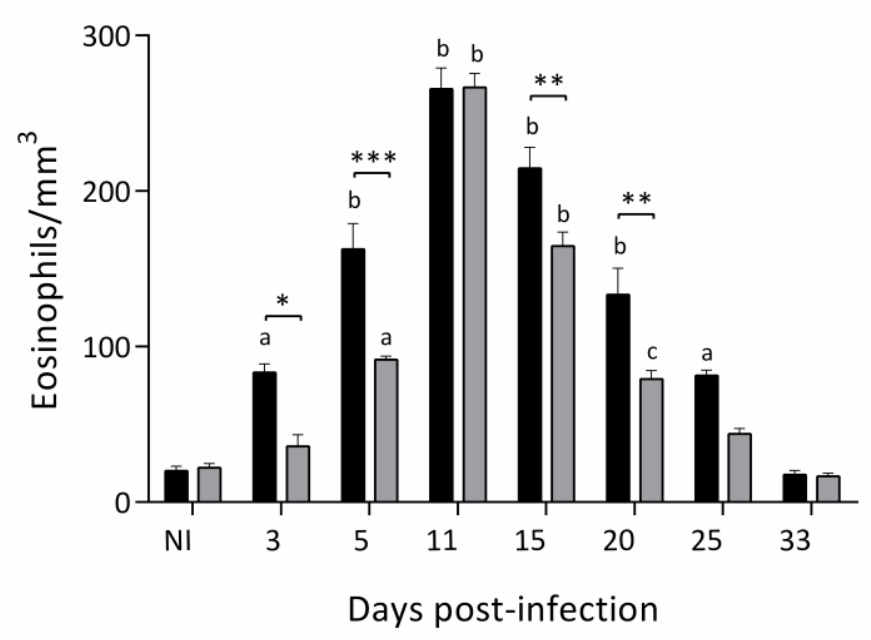

Fig. 2. Blood eosinophils counts during $T$. spiralis infection. Eosinophils cells were counted in blood samples stained with Discombe's solution. Results are expressed as the mean cells $/ \mathrm{mm}^{3} \pm$ S.E.M. Animals groups $(\mathrm{n}=3$ /group) $\mathrm{C}$ and PD were infected with T. spiralis $\left(\mathrm{C}_{\mathrm{I}}\right.$ and $\left.\mathrm{PD}_{\mathrm{I}}\right)$ or non-infected $\left(\mathrm{C}_{\mathrm{NI}}\right.$ and $\left.\mathrm{PD}_{\mathrm{NI}}\right)$. Data were analyzed by two-way ANOVA test followed by Tukey's or Sidak's multiple comparisons test $(\alpha=$ 0.05). Asterisks indicate significant differences between $\mathrm{C}_{\mathrm{I}}$ and $\mathrm{PD}_{\mathrm{I}}(* P<0.05$; $* * P<$ $0.01 ; * * * P<0.0001)$. Letters indicate significant differences between $\mathrm{C}_{\mathrm{I}}$ or $\mathrm{PD}_{\mathrm{I}}$ with their non-infected control (a, $P<0.05$; b, $P<0.0001$, c, $P<0.01$ ). 


\section{Fig 3}
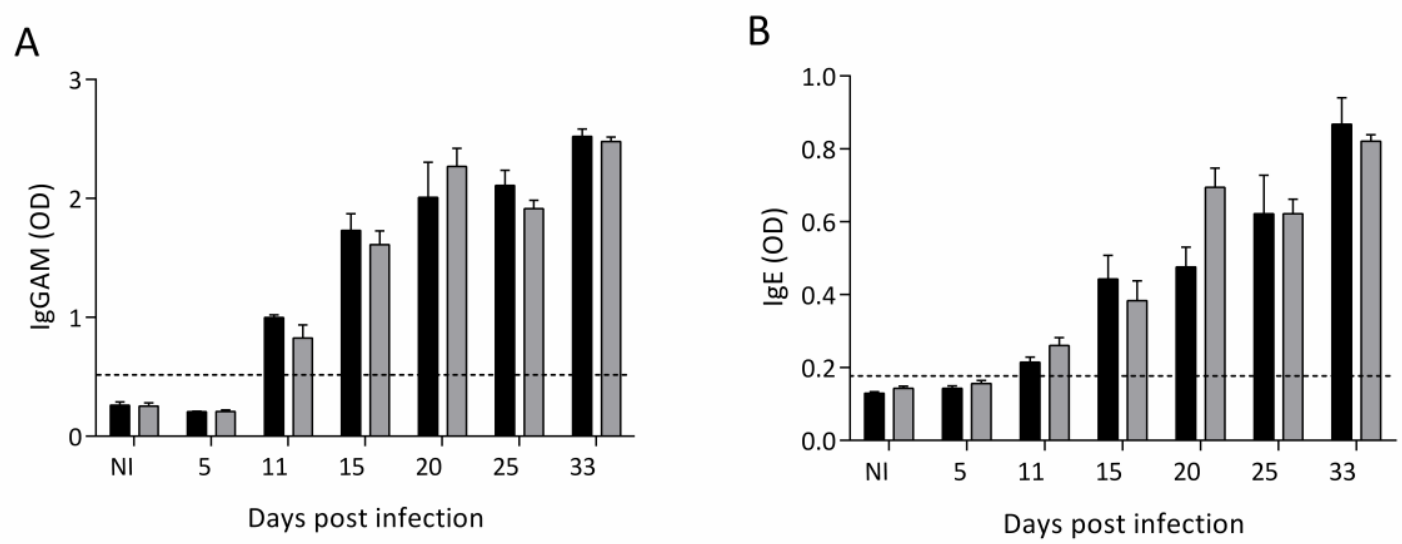

Fig. 3. Kinetics of total Igs (IgGAM) and IgE anti-ML-ESP in sera samples by ELISA during $T$. spiralis infection. IgGAM and IgE were detected by ELISA and results are expressed as mean O.D. values \pm S.E.M. $(n=3$ /group) (Cut-off: $\operatorname{IgE}=0.176$; IgGAM = 0.573). Animal groups were $C$ and $P D$ infected with $T$. spiralis $\left(C_{I}\right.$ and $\left.P D_{I}\right)$ or non-infected $\left(\mathrm{C}_{\mathrm{NI}}\right.$ and $\left.\mathrm{PD}_{\mathrm{NI}}\right)$. The dotted line indicates the cut-off. 
Fig. 4
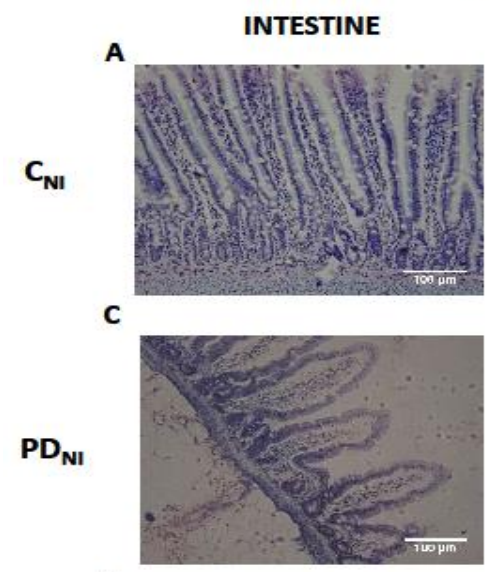

E

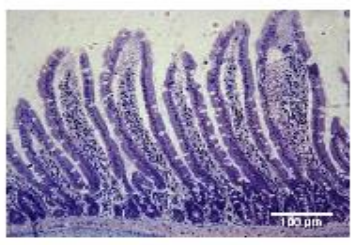

$c_{1}$

G

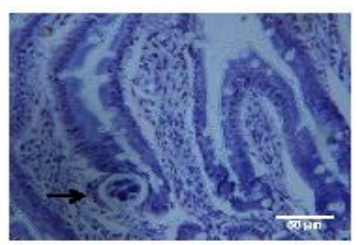

$\mathbf{P D}_{\mathbf{1}}$

I
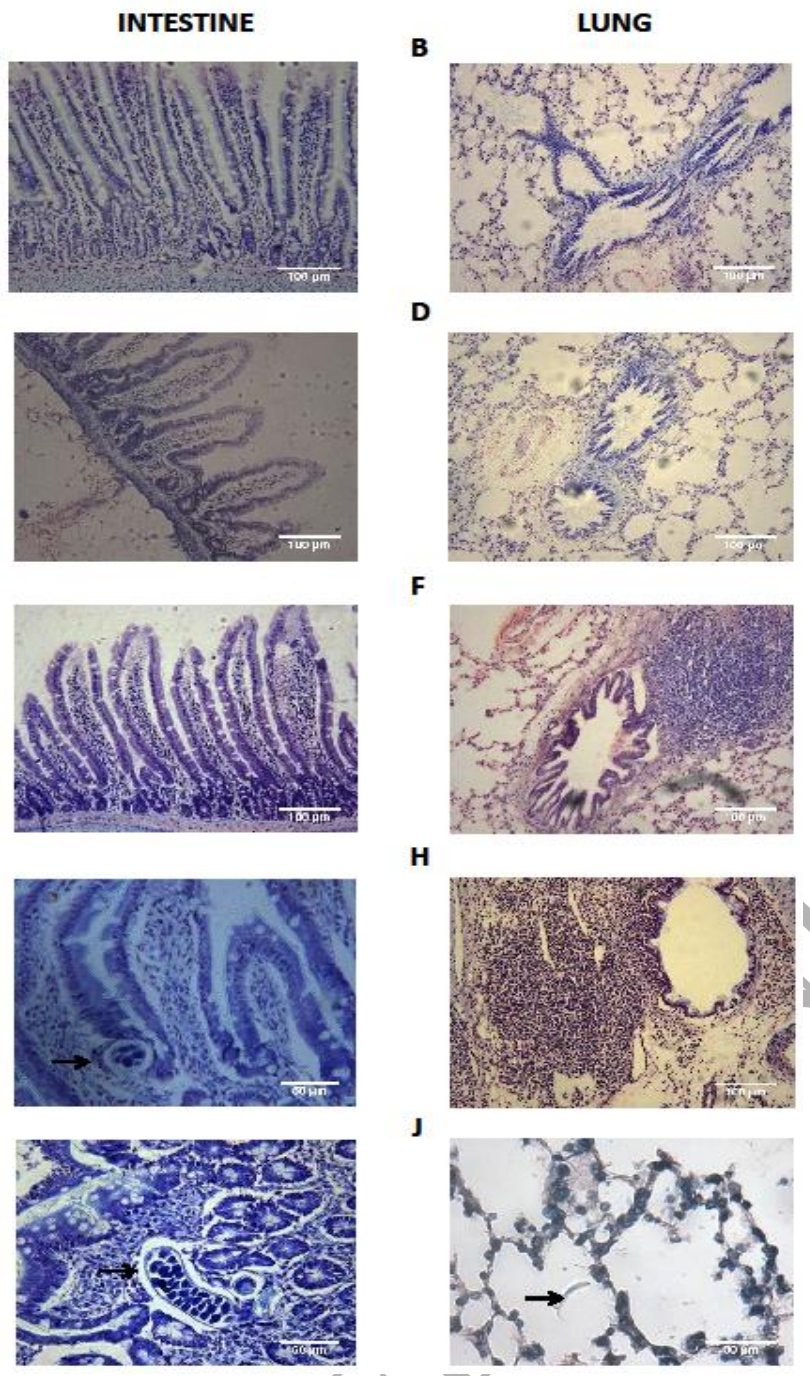

D

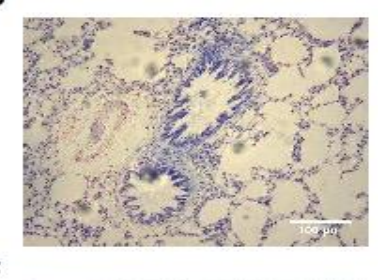

$\mathbf{F}$

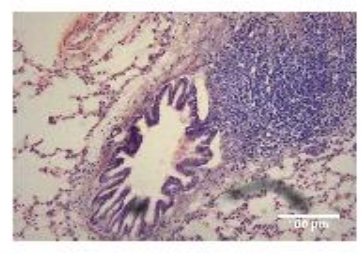

H

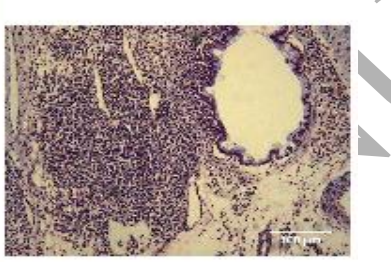

J

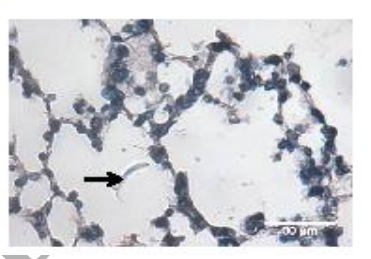

Fig. 4. Histopathology of the gut and lung during late $T$. spiralis infection. At day 33

p.i., histological sections of the gut (A, C, E, G, I) and lung (B, D, F, H, J) were stained with Giemsa. Animals groups were C (A, B, E, F) PD (C, D, G, H, I, J). Animals were infected with T. spiralis (E, F, G, H, I, J) and non-infected animals were used as controls (A, B, C, D). The arrows show the presence of AW (G, I) and NBL (J). 
Fig. 5
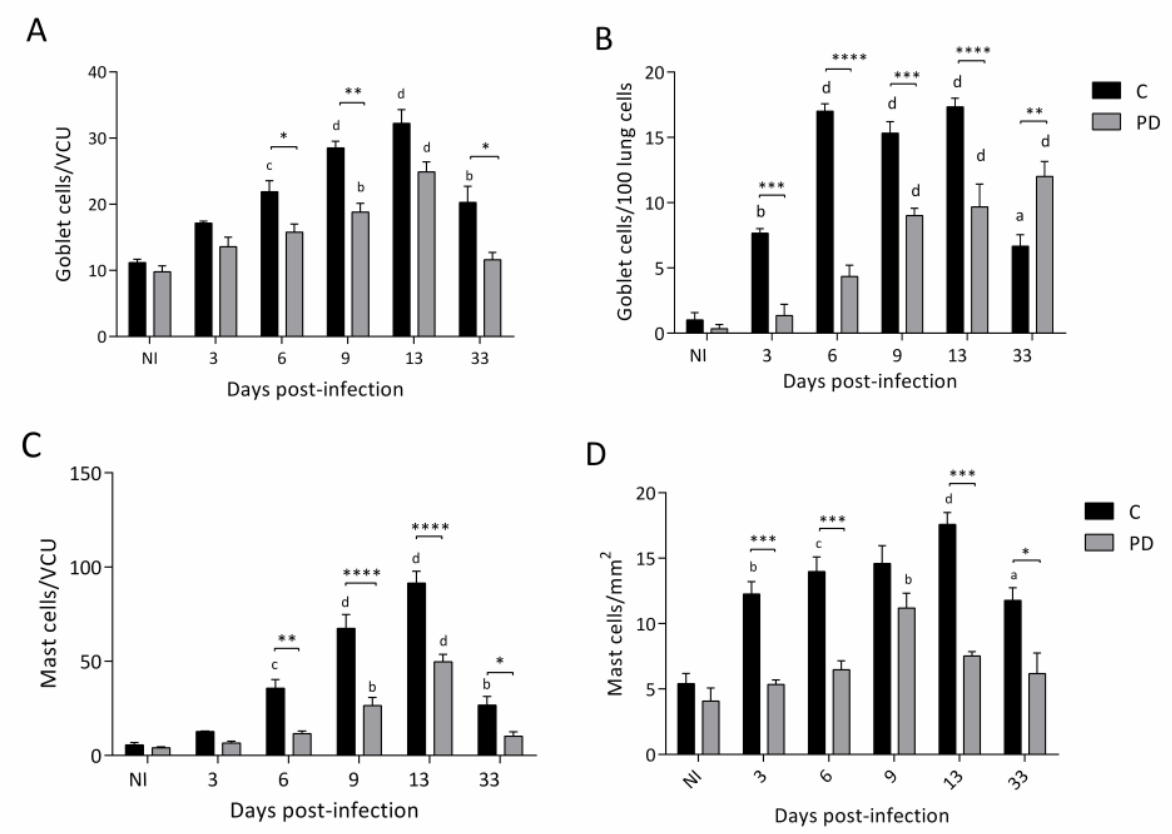

Fig. 5. Kinetics of the appearance of goblet and mast cells in the small intestine and lung during $\boldsymbol{T}$. spiralis infection. In gut, results are expressed as mean cells/VCU \pm S.E.M. (A, C). In lung, results are expressed as mean cells/100 lung cells \pm S.E.M. for goblet cells and mean cells $/ \mathrm{mm}^{2}$ of lung \pm S.E.M for the mast cells (B, D). Animals groups ( $\mathrm{n}=3$ /group) were $\mathrm{C}$ and $\mathrm{PD}$ then infected with $T$. spiralis $\left(\mathrm{C}_{\mathrm{I}}\right.$ and $\left.\mathrm{PD}_{\mathrm{I}}\right)$ or noninfected $\left(\mathrm{C}_{\mathrm{NI}}\right.$ and $\left.\mathrm{PD}_{\mathrm{NI}}\right)$. Data were analyzed by two-way ANOVA test followed by Sidak's multiple comparisons test $(\alpha=0.05)$. The asterisks indicate significant differences between $\mathrm{PD}_{\mathrm{I}}$ and $\mathrm{C}_{\mathrm{I}}(* P<0.05$; ** $P<0.01$; *** $P<0.005$; **** $P<$ 0.001 ) and letters indicate significant differences between $\mathrm{PD}_{\mathrm{I}}$ or $\mathrm{C}_{\mathrm{I}}$ with their noninfected control (a, $P<0.05$; b $P<0.01$; c, $P<0.005$; d, $P<0.001)$. 
Fig. 6
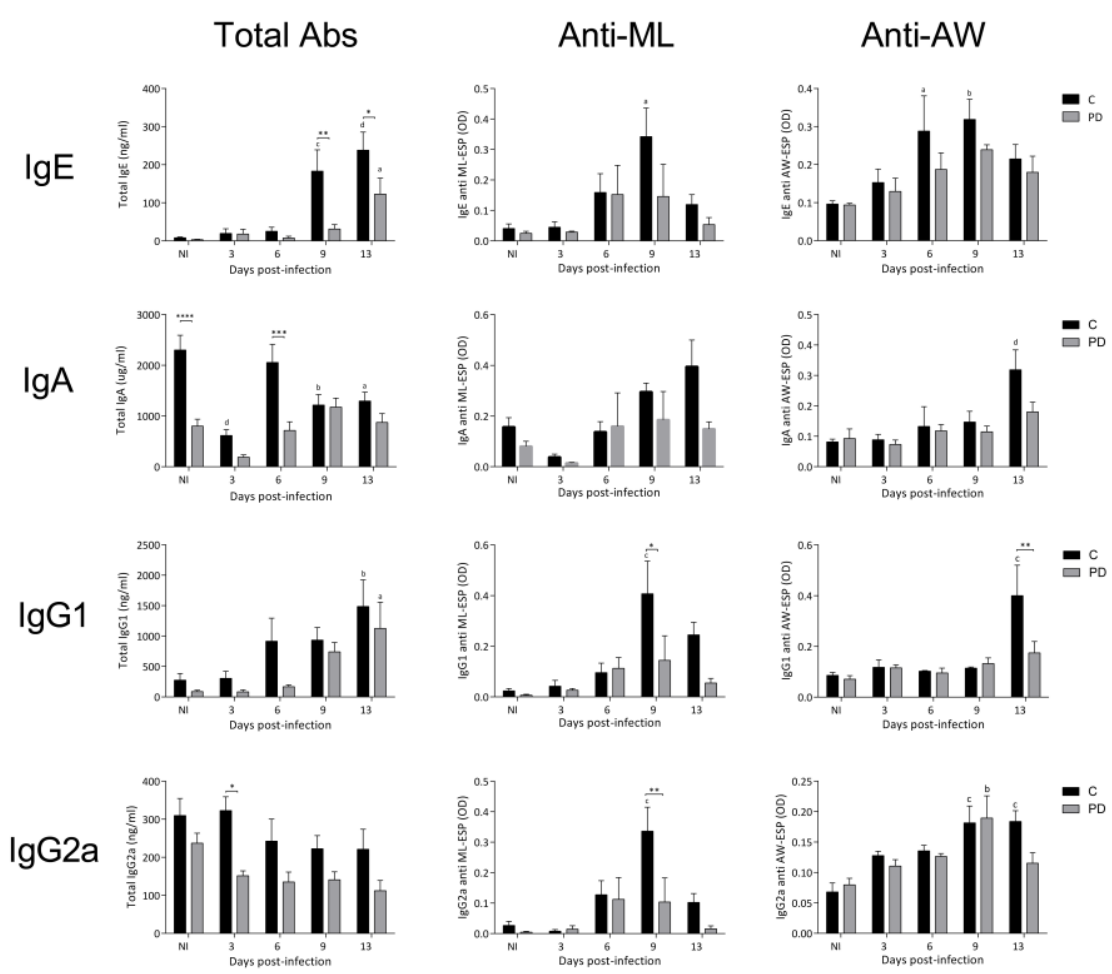

Fig. 6. Kinetics of total, anti-ML-ESP and anti-AW-ESP Igs in ITE during $T$. spiralis infection. Total Igs concentrations were determined by ELISA and are expressed as concentration \pm S.E.M. Specific Igs were determined by ELISA and are expressed as their OD values \pm S.E.M. Animals groups $(n=5 /$ group $)$ were $C$ and PD rats infected with $T$. spiralis $\left(\mathrm{C}_{\mathrm{I}}\right.$ and $\left.\mathrm{PD}_{\mathrm{I}}\right)$ or non-infected $\left(\mathrm{C}_{\mathrm{NI}}\right.$ and $\left.\mathrm{PD}_{\mathrm{NI}}\right)$. Data were analyzed by two-way ANOVA test followed by Tukey's or Sidak's multiple comparisons test $(\alpha=0.05)$. The asterisks indicate significant differences between PD and $C(* P<0.05$, ** $P<0.01, * * * P<0.005$, **** $P<0.001)$ and letters indicate significant differences between $\mathrm{PD}_{\mathrm{I}}$ or $\mathrm{C}_{\mathrm{I}}$ with their non-infected control (a, $P<0.05$; $\mathrm{b}$, $P<0.01 ; \mathrm{c}, P<0.005 ; \mathrm{d}, P<0.0001)$. 
Fig. 7
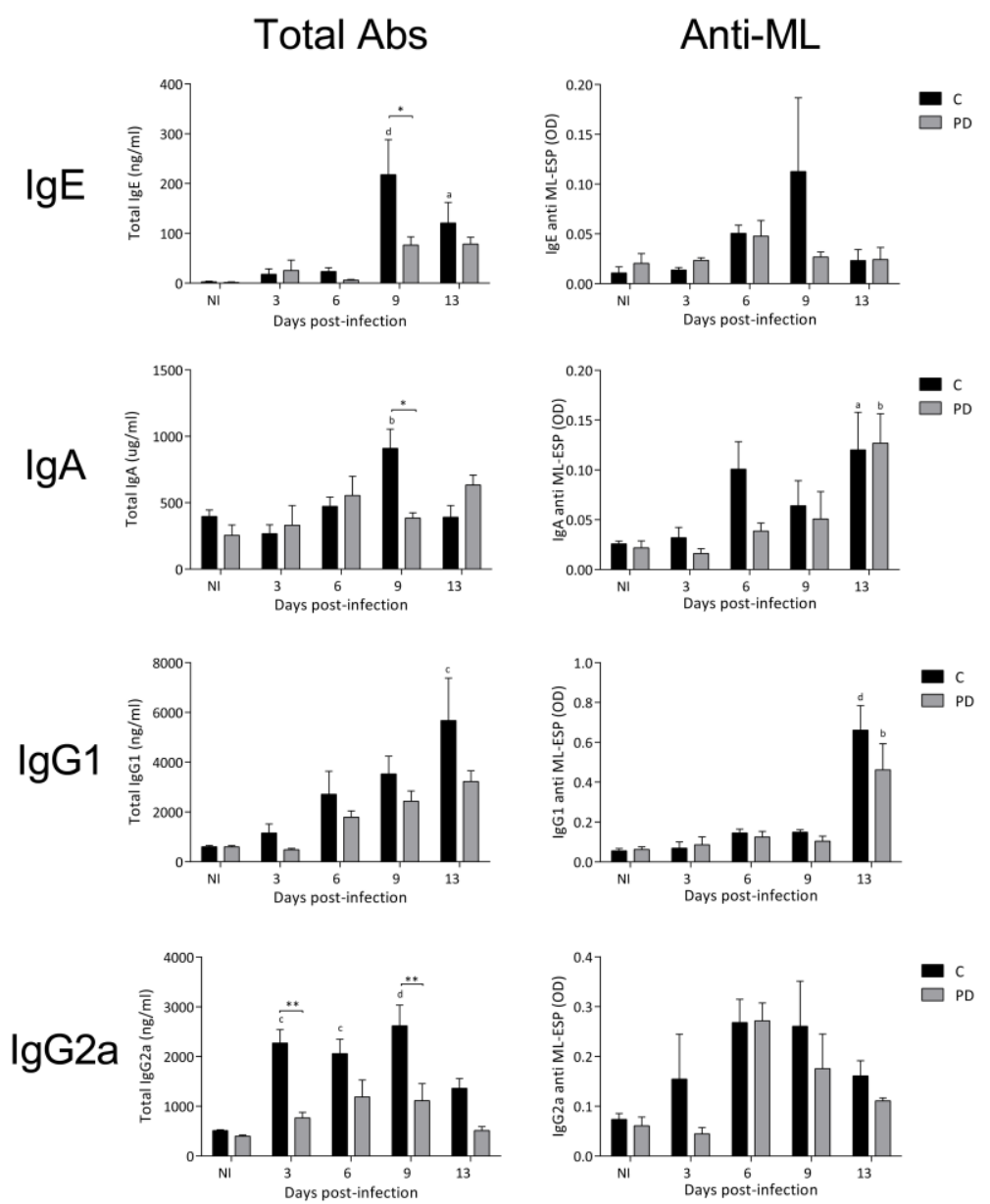

Fig. 7. Kinetics of total and anti-ML-ESP Igs in LTE during T. spiralis infection.

Total Igs concentrations were determined by ELISA and are expressed as concentration \pm S.E.M. Specific Igs levels are determined by ELISA and were expressed as their OD values \pm S.E.M. Animals groups $(\mathrm{n}=5$ /group) were $\mathrm{C}$ and $\mathrm{PD}$ rats infected with $T$. spiralis $\left(\mathrm{C}_{\mathrm{I}}\right)$ and $\left.\mathrm{PD}_{\mathrm{I}}\right)$ or non-infected $\left(\mathrm{C}_{\mathrm{NI}}\right.$ and $\left.\mathrm{PD}_{\mathrm{NI}}\right)$. Data were analyzed by two-way ANOVA test followed by Tukey's or Sidak's multiple comparisons test $(\alpha=0.05)$. The asterisks indicate significant differences between $\mathrm{PD}$ and $\mathrm{C}(* P<0.01, * * P<0.005)$ and letters indicate significant differences between $\mathrm{PD}_{\mathrm{I}}$ or $\mathrm{C}_{\mathrm{I}}$ with their non-infected control (a, $P<0.05$; b $P<0.01$; c $P<0.005$; d, $P<0.0001)$. 
Fig. 8

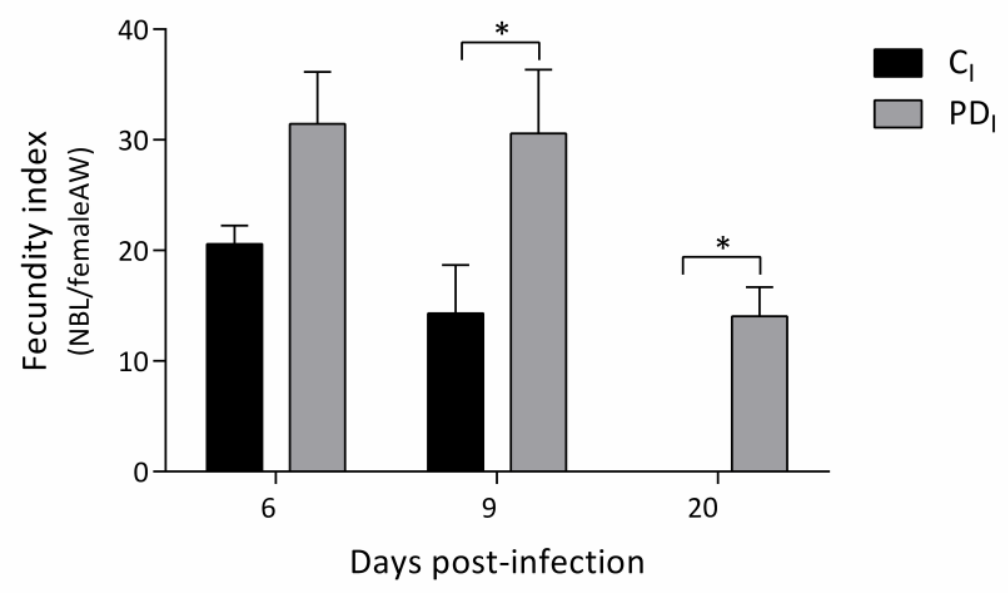

Fig. 8. Fecundity index of female AW during acute phase of $T$. spiralis. After recovery of AW females were identified and counted. AW were incubated during $3 \mathrm{~h}$ and the number of NBL shed by female AW were counted using an inverted microscope. The fecundity index was calculated as the number of NBL/female AW \pm S.E.M. Animals groups $\left(\mathrm{n}=4\right.$ /group) were rats $\mathrm{C}$ and $\mathrm{PD}$ infected with $T$. spiralis $\left(\mathrm{C}_{\mathrm{I}}\right.$ and $\left.\mathrm{PD}_{\mathrm{I}}\right)$. Data were expressed as mean number of $\mathrm{NBL} /$ female $\mathrm{AW} \pm \mathrm{S}$.E.M analyzed by two-way ANOVA followed by Sidak's multiple comparisons test $(\alpha=0.05, \mathrm{n}=$ 4/group). Asterisk indicates significant differences between $\mathrm{PD}_{\mathrm{I}}$ and $\mathrm{C}_{\mathrm{I}}$ groups $(* P<$ $0.05)$. 
Fig. 9

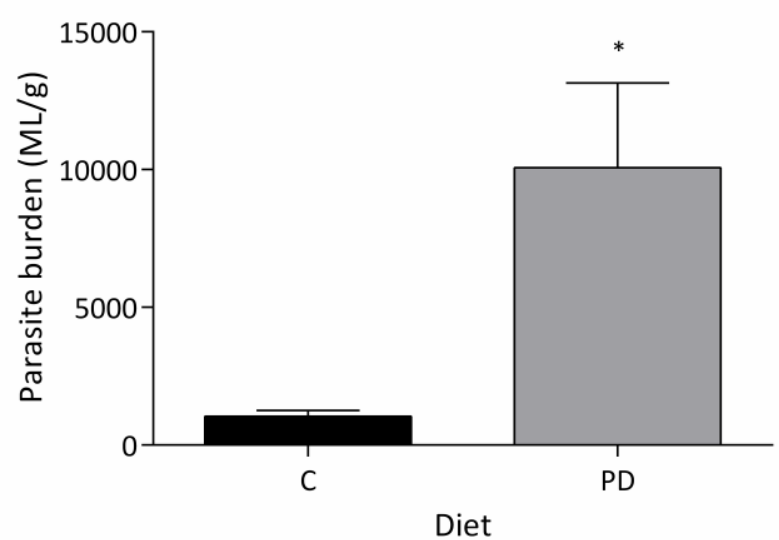

Fig. 9. Parasite burden of animals at day 33 p.i. Parasite burden of the animals was determined by artificial digestion and results are expressed as the mean of the ML/g rat \pm S.E.M. Animals groups $(\mathrm{n}=5$ /group) were rats $\mathrm{C}$ and $\mathrm{PD}$ infected with $T$. spiralis. Data was analysed using the unpaired $t$ test $(\alpha=0.05)$ and the asterisk indicates significant differences $(* P<0.01)$.

Table 1. Nutritional parameters evaluated before and during infection with $T$. spiralis. Ponderal growth rate (PGR), body weight (BW), food, energy and protein intake were evaluated during the experimental period of 43 days in rats fed a $20 \%$ casein diet (C) or a $6.5 \%$ casein diet (PD).

\begin{tabular}{|c|c|c|c|c|c|c|c|}
\hline \multirow{2}{*}{$\begin{array}{l}\text { period } \\
\text { ay) }\end{array}$} & \multirow[t]{2}{*}{ Group } & \multirow{2}{*}{$\begin{array}{c}\text { PGR } \\
\text { /100g rat/day) }\end{array}$} & \multicolumn{2}{|c|}{$\mathrm{BW}(\mathrm{g})$} & \multirow{2}{*}{$\begin{array}{l}\text { Food Intake } \\
\qquad \text { (g/day) }\end{array}$} & \multirow{2}{*}{$\begin{array}{l}\text { Energy Intake } \\
\text { (Kcal/BW }{ }^{0.75} / \text { day) }\end{array}$} & \multirow{2}{*}{$\begin{array}{l}\text { Protein In } \\
\left(\mathrm{mg} / \mathrm{BW}{ }^{0.75}\right.\end{array}$} \\
\hline & & & BWi & $\mathrm{BW}_{\mathrm{f}}$ & & & \\
\hline & $\mathrm{PD}_{\mathrm{I}}$ & $1.53 \pm 0.73^{\mathrm{a}}$ & $41.76 \pm 1.87$ & $48.02 \pm 2.32^{\mathrm{e}}$ & $6.57 \pm 0.64^{c}$ & $2.39 \pm 0.19$ & $33.91 \pm 1$ \\
\hline nfection & $\mathrm{PD}_{\mathrm{NI}}$ & $1.26 \pm 0.94^{\mathrm{a}}$ & $43.05 \pm 2.31$ & $47.98 \pm 1.51^{\mathrm{e}}$ & $6.30 \pm 0.88^{c}$ & $2.36 \pm 0.26$ & $28.73 \pm 2$ \\
\hline -9) & $\mathrm{C}_{\mathrm{I}}$ & $6.69 \pm 0.57^{b}$ & $41.18 \pm 1.56$ & $76.68 \pm 2.04^{f}$ & $9.48 \pm 1.15^{\mathrm{d}}$ & $2.61 \pm 0.30$ & $108.80 \pm ?$ \\
\hline & $\mathrm{C}_{\mathrm{NI}}$ & $6.04 \pm 0.95^{b}$ & $42.84 \pm 1.97$ & $75.02 \pm 2.97^{f}$ & $9.58 \pm 0.77^{d}$ & $2.62 \pm 0.20$ & $110.77 \pm ?$ \\
\hline & $\mathrm{PD}_{\mathrm{I}}$ & $0.30 \pm 0.46^{\mathrm{c}}$ & $48.02 \pm 2.32^{\mathrm{e}}$ & $55.67 \pm 1.87^{\mathrm{e}}$ & $9.33 \pm 1.70^{\mathrm{e}}$ & $2.00 \pm 0.93$ & $31.23 \pm 3$ \\
\hline nfection & $\mathrm{PD}_{\mathrm{NI}}$ & $1.22 \pm 0.48^{\mathrm{d}}$ & $47.98 \pm 1.51^{\mathrm{e}}$ & $73.64 \pm 2.62^{f}$ & $8.75 \pm 0.91^{e}$ & $1.63 \pm 0.40$ & $25.36 \pm 1$ \\
\hline
\end{tabular}




\begin{tabular}{lccccccc}
\hline )-43) & $\mathrm{C}_{\mathrm{I}}$ & $2.21 \pm 0.52^{\mathrm{d}}$ & $76.68 \pm 2.04^{\mathrm{f}}$ & $174.80 \pm 4.47^{\mathrm{g}}$ & $15.89 \pm 2.17^{\mathrm{f}}$ & $1.70 \pm 0.66$ & $62.45 \pm 4$. \\
\cline { 2 - 7 } & $\mathrm{C}_{\mathrm{NI}}$ & $2.25 \pm 0.65^{\mathrm{d}}$ & $75.02 \pm 2.97^{\mathrm{f}}$ & $174.40 \pm 5.03^{\mathrm{g}}$ & $14.77 \pm 1.07^{\mathrm{f}}$ & $1.61 \pm 0.20$ & $76.96 \pm 1$. \\
\hline & $\mathrm{PD}_{\mathrm{I}}$ & $0.63 \pm 0.35^{\mathrm{e}}$ & $41.76 \pm 1.87$ & $55.67 \pm 1.87^{\mathrm{e}}$ & $8.83 \pm 1.68^{\mathrm{e}}$ & $1.95 \pm 0.82$ & $31.26 \pm 3$. \\
\cline { 2 - 7 } otal & $\mathrm{PD}_{\mathrm{NI}}$ & $1.22 \pm 0.61^{\mathrm{f}}$ & $43.05 \pm 2.31$ & $73.64 \pm 2.62^{\mathrm{f}}$ & $8.12 \pm 0.87^{\mathrm{e}}$ & $1.56 \pm 0.40$ & $25.06 \pm 1$. \\
\cline { 2 - 7 } & $\mathrm{C}_{\mathrm{I}}$ & $2.87 \pm 0.40^{\mathrm{f}}$ & $41.18 \pm 1.56$ & $174.80 \pm 4.47^{\mathrm{g}}$ & $14.25 \pm 1.94^{\mathrm{f}}$ & $1.71 \pm 0.61$ & $84.46 \pm 4$ \\
\hline $\mathrm{C}_{\mathrm{NI}}$ & $2.81 \pm 0.30^{\mathrm{f}}$ & $42.84 \pm 1.97$ & $174.40 \pm 5.03^{\mathrm{g}}$ & $13.45 \pm 0.92^{\mathrm{ef}}$ & $1.63 \pm 0.25$ & $80.28 \pm 1$
\end{tabular}

$\mathrm{PD}_{\mathrm{I}}=\mathrm{PD}$ infected; $\mathrm{PD}_{\mathrm{NI}}=\mathrm{PD}$ non-infected; $\mathrm{C}_{\mathrm{I}}=\mathrm{C}$ infected; $\mathrm{C}_{\mathrm{NI}}=\mathrm{C}$ non-infected; $\mathrm{BW}_{\mathrm{i}}=$ initial $\mathrm{BW}$; $\mathrm{BW}_{\mathrm{f}}=\mathrm{BW}$ final. Data are expressed as mean \pm S.E.M., $\mathrm{n}=5$ /group. For PGR, food, energy and protein intake a one-way ANOVA test was performed and for BW a two-way ANOVA test was performed. In all cases, a $P<0.05$ was considered significant, and Tukey's multiple comparisons test for second análysis was used. Comparisons among the four experimental groups were performed for each parameters and for each feeding period. a $v s$. b $P<0.001$; c vs. d $P<0.01$; e $v s$. f $P<0.05$; f $v s$. g $P<0.001$; $v s$. i $P<$ 0.005 . 